\title{
PENGARUH PEMBERIAN TEPUNG BIJI NANGKA SEBAGAI BAHAN PENGISI TERHADAP KUALITAS BAKSO DAGING ITIK PETELUR AFKIR
}

\author{
Feri Fariadin, Permata Ika Hidayati, Dyah Lestari Yulianti \\ Fakultas Peternakan \\ Universitas Kanjuruhan Malang \\ Email: permata@unikama.ac.id
}

\begin{abstract}
Abstrak
Penelitian ini untuk mengetahui pengaruh penggunaan tepung biji nangka sebagai bahan pengisi terhadap kualitas bebek. Bahan yang digunakan dalam penelitian ini adalah tepung biji nangka 0\% (P0), 5\% (P1), 10\% (P2), 15\% (P3) dan 20\% (P4) Metode ini menggunakan Group Random Design (RAL) dengan empat pengulangan. Menggunakan data analisis varians tunggal. Hasil uji organoleptik dan penyusutan masakan menunjukkan bahwa pada perlakuan P0 dan P1 dengan tingkat pati biji naga $0-5 \%$ terdapat efek nyata $(\mathrm{P}<0,01)$. Sedangkan pada P2, P3 dan P4 tidak mempengaruhi elastisitas, aroma, rasa, warna dan tekstur yang baik. Inilah sebabnya mengapa penambahan kadar pati akan menurun. Disarankan dalam proses pembuatan bakso daging itik dengan menggunakan tepung tapioka 95\% dengan bibit kanji biji 5\%
\end{abstract}

Kata kunci: tepung; biji nangka; bakso; itik afkir

\section{THE INFLUENCE OF THE USE OF JACKFRUIT SEED FLOUR AS A FILLER MATERIAL TO THE QUALITY OF MEATBALLS DUCK LAYING DUCK MEATBALLS}

\begin{abstract}
This research to know the effect of the use of jackfruit seed flour as a filler material to the quality of laying duck meatballs. The material used in this study were jackfruit flour $0 \%(\mathrm{P} 0)$, 5\% (P1), 10\% (P2), 15\% (P3) and 20\% (P4) This method uses Group Random Design (RAL) with four repetitions. Using single variance analysis data. The results of organoleptic test and cooking shrinking showed that in the treatment of P0 and P1 with the seed starch level of 0-5\% jackfruit there was a very real effect $(\mathrm{P}<0.01)$. While on P2, P3 and P4 does not influence good elasticity, aroma, taste, color and texture. This is why the more the addition of starch level will decrease. Suggested in the process of making meatballs duck meat using $95 \%$ tapioca starch with 5\% starch seed jackfruit.
\end{abstract}

Keywords: flour, seed jackfruit, meatball, laying duck

\section{PENDAHULUAN}

Pada tahun 2013 konsumsi tepung tapioka mencapai 3.33 juta ton, sedangkan produksi tepung tapioka di Indonesia hanya sekitar 1.2 juta ton. Hal ini memaksa Indonesia untuk melakukan impor tepung tapioka. Untuk memenuhi kebutuhan tersebut, dapat dilakukan dengan memanfaatkan bahan hasil pertanian yang selama ini belum diolah sehingga akan memberikan nilai tambah dalam rantai pengolahan hasil pertanian. Salah satu limbah pada pemanfaatan buah nangka adalah biji dari buah nangka. Data produksi buah nangka pada tahun 2012 diIndonesia sebesar 652.981 ton (Badan Pusat Statistik, 2012). Potensi biji nangka (Arthocarphusheterophilus) yang besar belum dieksploitasisecara optimal. Masih rendahnya pemanfaatan biji nangka dalam bidang pangan hanya sebatas sekitar $10 \%$ disebabkan kurang minat masyarakat dalam 


\section{Jurnal Sains Peternakan}

Vol 6, No 1, Juni 2018, pp: 33-41

ISSN $2579-4450$

pengolahan biji nangka.

Hettiatchi, Ekanayake and Welihinda (2011) menyatakan disetiap 100 gram biji nangka mengandung karbohidrat 21 gram protein, 4,7 gram, lemak 1,3 gram, pati 1,3 gram dan amilosa 5,4 gram Irwansyah (2010) menyatakan amilum biji nangka mengandung 83,73 amilopektin dan 16,23\% amilosa. Menurut Direktorat Giji, Depkes RI (2010) setiap 100 gram dalam biji nangka tinggi akan kalsium (33 mg) dan fosfor (200 $\mathrm{mg}$ ). Peranan kalsium dan fosfor bagi tubuh manusia diantaranya adalah untuk pembentukan tulang dan gigi (Winarno, 2004).

Untuk meningkatkan nilai ekonomis biji nangka dapat diolah menjadi tepung. Tepung biji nangka dapat digunakan sebagai bahan alternatif pengganti tepung tapioka.Pembuatan tepung biji nangka juga merupakan suatu usaha penyimpanan agar lebih tahan lama karena buah nangka merupakan buah musiman yang banyak berbuah pada bulan Agustus-November, pada bulan lain sulit ditemukan (Suprapti, 2004).

Proses pembuatan tepung biji nangka sangat mudah biji nangka yang sudah masak yang dilakukan pencucian, perebusan selama 30 menit dilakukan pengupasan kulit arinya, dilakukan pengirisan dan dikeringkan di oven pada suhu $60-100^{\circ} \mathrm{C}$ selama 4 jam untuk menurunkan kadar air kemudian dilakukan penggilingan untuk menghasilkan tepung biji nangka (Winarti dan Purnomo, 2006).

Populasi itik di Indonesia setiap tahun mengalami peningkatan. Berdasarkan data statistik tahun 2009 - 2010, populasi itik di Jawa Barat meningkat dari 8.200.958 ekor pada tahun 2009 menjadi 9.871.091 ekor pada tahun 2010 (Dinas Peternakan Provinsi Jawa Barat, 2011). Mengingat populasi itik yang cukup banyak dan memiliki kandungan gizi yang tidak jauh berbeda dengan ayam broiler maka dagingitik cukup potensial untuk dijadikan sebagai penyedia protein hewani.

Daging itik memiliki karakteristik yang berbeda dengan daging ayam broiler, yaitu memiliki warna yang lebih merah, bau lebih anyir/amis, tekstur daging yang alot, dan kandungan lemak yang lebih tinggi (Srigandono, 1997). Hal ini menyebabkan penerimaan konsumen terhadap daging itik masih terbatas.Pengolahan merupakan suatu upaya untuk memperbaiki kelemahan yang dimiliki daging itik petelur afkir di antaranya melaluipenggunaan tepung biji nangka sebagai bahan pengisi terhadap kualitas bakso daging itik petelur afkir.

Bakso adalah bahan pangan yang terbuat dari daging sebagai bahan utama, baik daging itik, sapi, ayam, ikan, maupun udang. Bakso merupakan daging yang telah dihaluskan dan dicampur dengan bahan tambahan lain serta bumbu-bumbu sehingga bakso menjadi lebih lezat. Umumnya bakso dibentuk menjadi bulatan-bulatan 


\section{Jurnal Sains Peternakan}

Vol 6, No 1, Juni 2018, pp: 33-41

ISSN $2579-4450$

menyerupai bola.Cita rasa bakso yang lezat dan tekstur yang kenyal menjadikan bakso disukai anak-anak hingga orang dewasa. Bakso umumnya diolah menjadi beragam hidangan seperti bakso kuah, bakso panggang, sate bakso, tumis bakso dan beragam hidangan bakso lainnya.Penelitian ini bertujuan bagaimana pengaruh penggunaan tepung biji nangka sebagai bahan pengisi terhadap kualitas bakso daging itik petelur afkir.

\section{MATERI DAN METODE}

Materi yang digunakan adalah daging itik petelur afkir sebagai bahan dasar dalam pembuatan bakso yang berkualitas baik, karena kualitas daging sangat berpengaruh besar dalam menghasilkan bakso yang baik. Daging itik untuk penelitian ini di dapat dari peternak itik petelur di Desa Singgahan Sanan Kerto Turen Malang. Tepung yang digunakan untuk bahan pengisi yaitu tepung biji buah nangka biji yang di dapat dari toko buah pinggir jalan di Malang. Setelah membeli biji buah nangka kemudian biji tersebut diolah menjadi tepung.

Metode penelitian yang digunakan adalah dengan menggunakan berbagai level tepung biji nangka pada bakso daging itik petelur afkir. Tujuan penelitian ini untuk mengetahui kualitas bakso pada berbagai level tepung biji nangka. Variabel yang diamati dalam penelitian ini meliputi variabel bebas yaitu level tepung nangka, sedangkan untuk variabel terikat, yaitu uji organoleptik dan daya susut masak.

\section{Uji Organoleptik}

Uji Organoleptik dilakukan dengan menggunakan 15 penelis yang akan menilai bakso melalui panca indra agar dapat diketahui tingkat kesukaan konsumen terhadap bakso tepung biji nangka yang diuji berdasarkan level penambahan tepung. Penilaian menggunakan panca indra ini meliputi deskripsi kekenyalan, aroma, rasa, warna, dam teekstur. Tujuan melakukan uji organoleptik untuk menganalisis kecenderungan selera konsumen pada bakso dengan bahan pengisi tepung tepung biji nangka berdasarkan penambahan level.

\section{Uji Daya Susut Masak}

Uji susut masak menunjukkan banyaknya air dan lemak yang hilang selama pemasakkan. Bakso mentah ditimbang, dimasak, lalu ditimbang kembali. Susut masak diperoleh dengan menggunakan rumus:

$$
\begin{aligned}
& \text { Susut Masak }=\frac{(a-b)}{a} \times 100 \% \\
& \mathrm{a}: \text { bobot bakso mentah }(\mathrm{g}) \\
& \mathrm{b}: \text { bobot bakso setelah dimasak }(\mathrm{g})
\end{aligned}
$$




\section{Jurnal Sains Peternakan}

Vol 6, No 1, Juni 2018, pp: 33-41

ISSN $2579-4450$

\section{Analisa Data}

Rancangan penelitian yang digunakan dalam penelitian ini ialah rancangan acak lengkap (RAL). Data yang diperoleh selama penelitian menggunakan analisis data anava varians tunggal apabila menunjukkan adanya perbedaan antar perlakuan maka dilanjutkan dengan uji lanjut duncan dan beda nyata terkecil (BNT) dengan tara signiikansi 0,01. Dengan menggunakan bantuan program SPSS 16.0

\section{HASIL DAN PEMBAHASAN}

Berdasarkan hasil penelitian menyatakan bahwa pembuatan bakso daging itik petelur afkir dengan menggunakan tepung biji nangka pada level 0-5\% memberikan pengaruh yang sangat nyata $(\mathrm{P}<0,01)$. Sedangkan pada level 10,15 dan $20 \%$ semakin terendah. Data menunjukkan bahwa semakin banyak substitusi pati biji nangka yang diberikan akan menyebabkan penurunan pada bakso daging itik. Dapat dilihat dari uji organoleptik (kekenyalan, aroma, rasa, warna dan tekstur). Penilaian organoleptik adalah penilaian mutu suatu produk dengan menggunakan indera manusia melalui syaraf sensorik. Penilaian dengan indera banyak digunakan untuk menilai hasil pertanian dan makanan. Penilaian dengan cara ini banyak disenangi karena dapat dilaksanakan dengan cepat dan langsung. Penentuan uji organoleptik terhadap kekenyalan, aroma, rasa, warna dan tekstur dilakukan dengan uji kesukaan terhadap 15 panelis. Berdasasrkan SNI 013818-1995 bahan pengisi dalam pembuatan bakso tidak boleh lebih dari $50 \%$. Peningkatan penggunaan bahan pengisi menyebabkan peningkatan kekerasan bakso (Purnomo, 1990). Hasil uji organoleptik terhadap level tepung biji nangka bakso daging itik petelur afkir disajikan pada Tabel 1 .

Tabel 1. Hasil uji organoleptik terhadap level tepung biji nangka bakso daging itik petelur afkir

\begin{tabular}{|c|c|c|c|c|c|}
\hline Level & Kekenyalan & Aroma & Rasa & Warna & Tekstur \\
\hline $0 \%$ & $3,80 \pm 0,41^{\mathrm{c}}$ & $3,80 \pm 0,41^{\mathrm{c}}$ & $3,87 \pm 0,35^{\mathrm{c}}$ & $3,87 \pm 0,52^{\mathrm{c}}$ & $3.60 \pm 0,64^{\mathrm{c}}$ \\
\hline $5 \%$ & $3,87 \pm 0,64^{\mathrm{c}}$ & $4,00 \pm 0,53^{\mathrm{c}}$ & $4,00 \pm 0,53^{\mathrm{c}}$ & $3,80 \pm 0,57^{\mathrm{c}}$ & $3,53 \pm 0,74^{c}$ \\
\hline $10 \%$ & $3,33 \pm 0,61^{\mathrm{bc}}$ & $3,60 \pm 0,64^{\mathrm{bc}}$ & $3,47 \pm 0,52^{\mathrm{bc}}$ & $3,47 \pm 0,84^{\mathrm{bc}}$ & $3,20 \pm 0,68^{\mathrm{bc}}$ \\
\hline $15 \%$ & $3,20 \pm 0,68^{\mathrm{ab}}$ & $3,13 \pm 0,63^{\mathrm{ab}}$ & $3,07 \pm 0,59^{\mathrm{ab}}$ & $2,53 \pm 0,84^{\mathrm{ab}}$ & $2,66 \pm 1,04^{\mathrm{ab}}$ \\
\hline $20 \%$ & $2,60 \pm 0,74^{\mathrm{a}}$ & $2,73 \pm 0,71^{\mathrm{a}}$ & $2,53 \pm 0,74^{\mathrm{a}}$ & $2,47 \pm 0,84^{\mathrm{a}}$ & $2,15 \pm 0,59^{a}$ \\
\hline Sig. & 0.00 & 0.00 & 0.00 & 0.00 & 0.00 \\
\hline
\end{tabular}

Berdasarkan hasil uji organoleptik menunjukan bahwa pada perlakuan P0 dan P1 dengan level $0-5 \%$ memberikan pengaruh yang sangat nyata $(\mathrm{P}<0,01)$ baik kekenyalan, aroma, rasa, warna, dan tekstur jika dilihat pada tabel 8 diatas. Sedangkan perlakuan terendah pada bagian P2, P3 dan P4 dengan level tepung 10-20\% semakin banyak 


\section{Jurnal Sains Peternakan}

Vol 6, No 1, Juni 2018, pp: 33-41

ISSN 2579-4450

penambahan level tepung maka akan semakin menurun. Hal ini disebabkan pati biji nangka yang digunakan adalah pati tanpa modifikasi yang mempunyai sifat tidak tahan dalam kondisi asam. Pati mudah terhidrolisis membentuk karbohidrat rantai lebih pendek pada kondisiasam. Hidrolisis pati ini mengurangi kemampuan gelatinisasinya (Kusnandar, 2010). Kandungan amilosa pada pati murni hal ini dikarenakan enzim amilase yang terkandung di dalamnya akan memecah amilosa menjadi maltosa. Maltosa yang merupakan disakarida akan kembali terpecah oleh enzim maltase menjadi glukosa dengan gugus aldehid. Gugus aldehid akan teroksidasi oleh udara $\left(\mathrm{O}_{2}\right)$ dan akan berubah menjadi asam karboksilat. Asam karboksilat inilah yang nantinya berperan (Kusnandar, 2010).

Suhu pemanasan yang meningkat juga membuat granula pati akan semakin mengembang dan tidak mampu lagi menampung air, sebagai akibatnya amilopektin rusak dan terperangkap dalam matriks yang terbentuk antara amilosa dan air lalu membentuk gel. Gelhasil bentukan dari amilosa lebih kokoh karena struktur amilosa yang linier lebih mudah berikatan sesama sendiri melalui ikatan hidrogen. Gel bentukan amilopektin cenderung lemah dalam mengikat air karena strukturnya yang besar akan membentuk ikatan hidrogen yang relatif lemah, semakin tinggi substitusi pati biji nangka maka semakin kecil kemampuan membentuk gel, yang mengakibatkan nilai semakin rendah (Kusnandar, 2010). Penentuan uji organoleptik terhadap kekenyalan, aroma, rasa, warna dan tekstur dilakukan dengan uji kesukaan terhadap 15 panelis.

\section{Pengaruh Perlakuan Terhadap Kekenyalan Bakso}

Berdasarkan hasil uji organoleptik terhadap kekenyalan menunjukan bahwa pada perlakuan P0 dan P1 dengan level 0\% dengan daya terikat 3,80 dan level 5\% dengan daya terikat 3,87 memberikan pengaruh yang sangat nyata $(\mathrm{P}<0,01)$ dapat menyimpulkan bahwa panelis cukup suka dengan kekenyalan bakso daging itik terhadap P0 dan P1. Kekenyalan bakso juga dipengaruhi oleh kualitas dan kuantitas daging yang digunakan, metode pengolahan dan bahan-bahan ditambahkan. Sedangkan perlakuan terendah pada bagian P2, P3 dan P4 dengan level tepung 10, 15 dan 20\% semakin banyak penambahan level tepung maka akan semakin menurun terhadap kualitas kekenyalan. Kekenyalan mempengaruhi palatabilitas seseorang terhadap suatu produk. Kekenyalan didasarkan pada kemudahan waktu mengunyah tampa kehilangan sifat-sifat jaringan yang layak. Terjadinya perbedaan nilai kekenyalan pada bakso dapat disebabkan oleh serat daging hal ini sesuai dengan penelitian Rahmatina (2010), yang menyatakan bahwa perbedaan nilai kekenyalan pada waktu pengolahan yang berbeda dapat disebabkan adanya perbedaan 


\section{Jurnal Sains Peternakan}

Vol 6, No 1, Juni 2018, pp: 33-41

ISSN $2579-4450$

serat pada masing-masing daging yang digunakan. Selanjutnya menurut Lawrie (2003), tingkat kekenyalan disebabkan oleh tiga kategori protein dalam urat daging, yaitu tenunan pengikat, miofibril dan sarkoplasma. Kekeuatan cairan urat daging (berasal dari koagulasi sarkoplasma) berfungsi sebagai bahan pengikat dalam bahan makanan yang dipanasi. Selain itu tergantung pada beberapa kondisi seperti kontraksi miofibril, tipe urat daging dan suhu pemasakan.

\section{Pengaruh Perlakuan Terhadap Aroma Bakso}

Berdasarkan hasil uji organoleptik terhadap aroma menunjukan bahwa pada perlakuan P0 dan P1 dengan level 0\% dengan daya terikat 3,80 dan level 5\% dengan daya terikat 4,00 memberikan pengaruh yang sangat nyata $(\mathrm{P}<0,01)$ dapat menyimpulkan bahwa panelis cukup suka dengan aroma bakso daging itik terhadap P0 dan P1. Sedangkan perlakuan terendah pada bagian P2, P3 dan P4 dengan level tepung 10, 15 dan $20 \%$ semakin banyak penambahan level tepung biji nangka maka akan semakin menurun terhadap kualitas aroma. Aroma suatu produk ditentukan saat zat-zat volatil masuk ke dalam saluran hidung dan ditanggapi oleh sistem penciuman (Meilgaard et al.,1999). Pembauan disebut pencicipan jarak jauh karena manusia dapat mengenal enaknya makanan yang belum melihat hanya dengan mencium baunya dari jarak jauh ( Soekarto, 1985). Aroma bakso dipengaruhi oleh spesies ternak, umur, jenis kelamin, makanan dan bahan -bahan ditambahkan selama pemasakan.

\section{Pengaruh Perlakuan Terhadap Rasa Bakso}

Berdasarkan hasil uji organoleptik terhadap rasa menunjukan bahwa pada perlakuan P0 dan P1 dengan level 0\% dengan daya terikat 3,87 dan level 5\% dengan daya terikat 4,00 memberikan pengaruh yang sangat nyata $(\mathrm{P}<0,01)$ dapat menyimpulkan bahwa panelis cukup suka dengan rasa bakso daging itik terhadap P0 dan P1. Sedangkan perlakuan terendah pada bagian P2, P3 dan P4 dengan level tepung 10, 15 dan 20\% semakin banyak penambahan level tepung biji nangka maka akan semakin menurun terhadap kualitas rasa. Hal ini sesuai Triatmodjo (1995), bahwa penggunaan bumbu yang tepat akan mengurangi dominasi rasa yang tidak disukai. Rasa bakso yang dihasilkan terutama disebabkan oleh bumbu-bumbu yang digunakan dan rasa daging selama pemasakan sehingga menimbulkan rasa yang utuh (Kartika et al., 1988, Tiven et al., 2007). Rasa dipengaruhi oleh senyawa kimia, suhu, kosentrasi, dan interaksi dengan komponen rasa yang lain (Winarno, 1988).

\section{Pengaruh Perlakuan Terhadap Warna Bakso}




\section{Jurnal Sains Peternakan}

Vol 6, No 1, Juni 2018, pp: 33-41

ISSN 2579-4450

Berdasarkan hasil uji organoleptik terhadap warna menunjukan bahwa pada perlakuan P0 dan P1 dengan level 0\% dengan daya terikat 3,87 dan level 5\% dengan daya terikat 3,80 memberikan pengaruh yang sangat nyata $(\mathrm{P}<0,01)$ dapat menyimpulkan bahwa panelis cukup suka dengan warna bakso daging itik terhadap P0 dan P1. Sedangkan perlakuan terendah pada bagian P2, P3 dan P4 dengan level tepung 10, 15 dan $20 \%$ semakin banyak penambahan level tepung biji nangka maka akan semakin menurun terhadap kualitas warna. Warna mempengaruhi penerimaan suatu bahan pangan, karena umumnya penerimaan bahan pertama kali dilihat adalah warna. Warna yang menarik akan meningkatkan penerimaan produk. Warna dapat mengalami perubahan dan pemasakan. Hal ini dapat disebabkan oleh hilangnya sebagian pigmen akibat pelepasan cairan sel pada saat pemasakan atau pengolahan, intesitas warna semakin menurun (Elviera, 1988). Warna suatu bahan berbeda-beda tergantung dari faktor alam, geografis dan aspek sosial masyarakat penerima (Winarno, 2002)

\section{Pengaruh Perlakuan Terhadap Tekstur Bakso}

Berdasarkan hasil uji organoleptik terhadap tekstur menunjukan bahwa pada perlakuan P0 dan P1 dengan level 0\% dengan daya terikat 3,60 dan level 5\% dengan daya terikat 3,53 memberikan pengaruh yang sangat nyata $(\mathrm{P}<0,01)$ dapat menyimpulkan bahwa panelis cukup suka dengan tekstur bakso daging itik terhadap P0 dan P1. Sedangkan perlakuan terendah pada bagian P2, P3 dan P4 dengan level tepung 10, 15 dan $20 \%$ semakin banyak penambahan level tepung biji nangka maka akan semakin menurun terhadap kualitas tekstur. Tekstur bakso juga dipengaruhi oleh kualitas dan kuantitas daging yang digunakan, metode pengolahan dan bahan-bahan ditambahkan. Lawrie (2003) menyatakan bahwa salah satu hal yang mempengaruhi tekstur daging adalah kandungan jaringan ikat serta berkas otot tekstur bakso ditentukan oleh kandungan air, kandungan lemak dan jenis karbo hidrat. Kandungan air yang tinggi akan menghasilkan bakso dengan tekstur yang lembek. Begitu juaga dengan lemak yang tinggi akan menghasilkan bakso yang berlubang-lubang sehingga dapat mempengaruhi tekstur bakso (Oktavianie, 2002).

\section{Susut Masak Bakso}

Susut masak adalah berat yang hilang selama proses pemasakan. Susut masak yang tinggi menunjukkan bahwa kemampuan emulsi dalam mengikat air dan lemak kecil. Tabel 2 menunjukkan bahwa semakin tinggi substitusi tepung biji nangka diiringi dengan 


\section{Jurnal Sains Peternakan}

Vol 6, No 1, Juni 2018, pp: 33-41

ISSN $2579-4450$

naiknya nilai susut masak, ini artinya penggunaan tepung biji nangka sebagai bahan pengisi (filler) mampu meningkatkan susut masak bakso

Tabel 2. Hasil pengaruh tepung dan level terhadap daya susut masak bakso daging itik petelur afkir

Level Tepung Biji Nangka

Daya Susut Masak

\begin{tabular}{lr}
\hline $0 \%$ & $0,87 \pm 0,55^{\mathrm{e}}$ \\
$5 \%$ & $0,84 \pm 0,46^{\mathrm{d}}$ \\
$10 \%$ & $0,54 \pm 0,45^{\mathrm{b}}$ \\
$15 \%$ & $0,44 \pm 0,23^{\mathrm{a}}$ \\
$20 \%$ & $0,72 \pm 0,25^{\mathrm{c}}$ \\
Sig & 0,00 \\
\hline
\end{tabular}

Keterangan : Notasi yang berbeda pada kolom yang sama menunjukan perbedaan sangat nyata $(\mathrm{P}<0,01)$.

Berdasarkan hasil uji dayat susut masak menunjukan bahwa pada perlakuan P0 dan $\mathrm{P} 1$ dengan level $0-5 \%$ memberikan pengaruh yang nyata $(\mathrm{P}<0,01)$ baik kekenyalan, aroma, rasa, warna, dan tekstur jika dilihat pada tabel 2 diatas. Sedangkan perlakuan terendah pada bagian P2, P3 dan P4 dengan level tepung 10-20\%. Bakso daging itiktepung biji nangka mempunyai rata-rata nilai susut masak tertinggi, karena kandungan amilopektin yang cukup tinggi pada pati biji nangka akan membentuk susunan matriks dan lemak dengan air pada bakso daging itik selama proses gelatinisasi, sehingga kandungan air bebas pada bakso banyak yang keluar pada saat pemanasan. Hal ini sesuai dengan pendapat Ockerman (1983) dalam Mega (2010), susut masak sangat dipengaruhi oleh hilangnya air selama pemasakan, keadaan ini dipengaruhi oleh protein yang dapat mengikat air, semakin banyak air yang ditahan oleh protein maka semakin sedikit air yang keluar sehingga susut masak berkurang.Susut masak dipengaruhi pula oleh daya ikat air. Daya ikat air menurun dengan substitusi tepung biji nangka, sehingga susut masak bakso daging itik meningkat. Pati biji nangka tidak dapat mengikat air bebas secara sempurna di dalam bakso sehingga kandungan air bebas banyak yang keluar pada saat pemasakan.

\section{KESIMPULAN}

Berdasarkan hasil penelitian didapatkan kesimpulan bahwa terdapat pengaruh perlakuan tertinggi susut masak dan uji organoleptik pada P1 dengan menggunakan tepung biji nangka 5\%. Sedangkan terendah pada $\mathrm{P} 4$ hal ini disebabkan semakin banyak penambahan level tepung biji nangka maka akan semakin menurun dikarenakan enzim amilase yang terkandung didalamnya akan memecah amilosa menjadi maltosa baik kekenyalan, aroma, rasa, warna dan tekstur 


\section{Jurnal Sains Peternakan}

Vol 6, No 1, Juni 2018, pp: 33-41

ISSN $2579-4450$

\section{UCAPAN TERIMA KASIH}

Ucapan terima kasih disampaikan kepada semua pihak terutama Laboratorium Terpadu Fakultas Peternakan Universitas Kanjuruhan Malang yang telah banyak membantu sejak persiapan hingga terselenggaranya penelitian ini dengan baik.

\section{DAFTAR PUSTAKA}

Badan Standarisasi Nasional. SNI 01 - 3818 - 1995. Mutu Bakso, Jakarta.

Dinas Peternakan Provinsi Jawa Barat.Populasi Itik Pada Tahun 2009-2010. Available online at http://disnak.jabarprov.go.id (Diakses tanggal 15 Januari 2017).

Departemen Bidang Pendayagunaan dan Pemasyarakatan Ilmu Pengetahuan dan Teknologi, 2007. Baso. http://www.ristek.go.id.[12 Maret 2017].

Elviera, G. 1988. Pengaruh pelayuan daging sapi terhadap mutu bakso. Skripsi. Institut Pertanian Bogor. Bogor.

Hettiaratchi UP, Ekanayake S, Welihinda J. 2011. Sri Lankan rice mixed meals: effect on glycaemic index and contribution to daily dietary fibre requirement. Malays $J$ Nutr. Apr;17(1):97-104.

Lawrie, R.A. 1995. Ilmu Daging. Edisi kelima. Terjemahan: Parakkasi, A dan Y. Amwila. Universitas Indonesia Press, Jakarta.

Purnomo, H. 1990. Kajian Mutu Bakso Daging, Bakso Urat Dan Bakso Aci Di Daerah Bogor. Skripsi. Fakultas Teknologi Pertanian. Bogor: Istitut Pertanian Bogor.

Srigandono, B. 1996. Beternak Itik. Gadjah Mada University Press, Yogyakarta.

Winarno, F.G. 2004. Kimia Pangan danGizi. Jakarta: Gramedia Pustaka Uta ma.

Winarti, S. \& Purnomo, Y. 2006. Olahan Biji Buah. Surabaya: Trubus Agrisa-rana. 